\title{
THE USE OF Eucalyptus camaldulensis AND Eucalyptus urophylla WOOD IN THE PRODUCTION OF EDGE GLUED PANELS
}

\author{
Setsuo Iwakiri ${ }^{1 *}$, Rosilani Trianoski ${ }^{2}$, Ângela Maria Stüpp ${ }^{3}$, Bruna Mulinari Cabral ${ }^{4}$, Jéssika Alvares \\ Coppi Arruda Gayer ${ }^{5}$ \\ 1 *Federal University of Paraná, Graduate Program in Forest Engineering, Curitiba, Paraná, Brazil - setsuo.ufpr@gmail.com \\ ${ }^{2}$ Federal University of Paraná, Graduate Program in Forest Engineering, Curitiba, Paraná, Brazil - rosilani@ufpr.br \\ ${ }^{3,4}$ Federal University of Paraná, Graduate Program in Forest Engineering, Curitiba, Paraná, Brazil - stuppmangela@ gmail.com; \\ brunacabral@florestal.eng.br \\ ${ }^{5}$ Federal University of Paraná, Graduate Program in Production Engineering, Curitiba, Paraná, Brazil - jessika.ac@ hotmail.com
}

Received for publication: 08/02/2018 - Accepted for publication: 08/11/2018

\begin{abstract}
This study aimed to evaluate the shear strength of bonded wood joints of Eucalyptus camaldulensis and Eucalyptus urophylla with vinyl polyacetate (PVA) and isocianate polymeric emulsion (EPI) adhesives with the amount of glue of 150 and $180 \mathrm{~g} / \mathrm{m}^{2}$. The specimens were submitted to shear tests in dry and wet conditions, based on the procedure described in standard EN 13354 (2008). The results of the 5th lower percentile were compared with the requirements of EN 13353 (2008). Among the studied species, Eucalyptus camaldulensis showed better glue line shear strength when compared to Eucalyptus urophylla. However, both species are potentially viable for the edge glued panel (EGP) production, since they meet the minimum requirement of $2.5 \mathrm{MPa}$, referring to the 5 th lower percentile, as established by EN 13353-2008 standard. Based on the results, it is recommended the use of EPI adhesive with the amount of glue of $150 \mathrm{~g} / \mathrm{m}^{2}$ for the bonding of the wood of these species, aiming at the production of EGP.

Keywords: Adhesives; vinyl polyacetate; isocianate polymeric emulsion.
\end{abstract}

\section{Resumo}

Utilização da madeira de Eucalyptus camaldulensis e Eucalyptus urophylla para produçao de painéis de colagem lateral. O objetivo deste trabalho foi avaliar a resistência ao cisalhamento das juntas coladas de madeiras de Eucalyptus camaldulensis e Eucalyptus urophylla com adesivos poliacetato de vinila (PVA) e emulsão polimérica de isocianato (EPI) com gramaturas de 150 e $180 \mathrm{~g} / \mathrm{m}^{2}$. Os corpos-deprova foram submetidos aos ensaios de cisalhamento nas condições a seco e a úmido, com base nos procedimentos descritos na norma EN 13354 (2008). Os resultados do $5^{\circ}$ percentil inferior foram confrontados com os requisitos da norma EN 13353 (2008). Entre as espécies estudadas, o Eucalyptus camaldulensis apresentou melhor resultado de resistência da linha de cola ao cisalhamento em comparação ao Eucalyptus urophylla. Entretanto, ambas as espécies são potencialmente viáveis para produção de painéis de colagem lateral (EGP) por terem atingido o requisito mínimo de 2,5 $\mathrm{MPa}$, referente ao $5^{\circ}$ percentil inferior, conforme estabelecido pela norma EN 13353-2008. Com base nos resultados, pode-se recomendar o uso do adesivo EPI com gramatura de $150 \mathrm{~g} / \mathrm{cm}^{2}$ para a colagem da madeira destas espécies, visando à produção de painéis EGP.

Palavras-chave: adesivos; poliacetato de vinila; emulsão polimérica de isocianato.

\section{INTRODUCTION}

The planted forests of Eucalyptus in Brazil comprise an area of 5.6 million hectares, being several species already used commercially for the production of cellulose and paper, charcoal, particleboard and fiberboard (ABRAF, 2013).

Among the less used species in commercial plantations, Eucalyptus camaldulensis and Eucalyptus urophylla, deserve special attention due to their silvicultural potential and the good characteristics of their wood. The E. camaldulensis stands out by the resistance to rot and high density of the wood - about 0.90 $\mathrm{g} / \mathrm{cm}^{3}$. Boland et al. (2006) describe the wood of E. camaldulensis as high density, and according to physiscist-mechanical properties, it is used in heavy construction, railway ties, floors, structural beams, fences, turned wood, in the production of firewood and coal, and in the manufacture of plywood.

The Eucalyptus urophylla is a species that presents great growth potential in terms of planted area due to the good productivity and quality of its wood. It presents an average basic density of $0.56 \mathrm{~g} / \mathrm{cm}^{3}$, with possibilities of use for the most diverse purposes, such as cellulose and paper, hard plates, sawmills and charcoal (JUNIOR and GARCIA, 2004). 
The use of wood in the form of saws presents some limitations, such as dimensions, anisotropy and natural defects, which affect its physical and mechanical properties. By means of gluing woods with adhesives, it is possible to manufacture reconstituted wood products with larger dimensions, greater dimensional stability and better distribution of mechanical resistance, with gains in quality and better costeffectiveness (IWAKIRI, 2005).

Among the reconstituted wood products, there is the Edge glued panel - EGP. The EGP is a panel composed of slats obtained from sawn wood and joined by side gluing, which may or may not be joined at the top by finger joints (TIENNE et al., 2011). In the production of EGP panels two types of adhesives are used, the polyvinyl acetate (PVA) and the polymer isocyanate emulsion (EPI).

PVA is the result of the polymerization of vinyl acetate and, according to Iwakiri (2005), this adhesive is popularly known as "white glue", being widely used by the wood industry and furniture for interior use. The product bonded with PVA presents high mechanical strength in dry environment, however, it has limitations of use in environments with high temperatures and relative humidity (PIZZI, 1983).

EPI is a bicomponent adhesive, consisting of a base of polyvinyl acetate and a polymeric isocyanate (diphenylmethane diisocyanate - MDI). This one has the function of catalyzing the adhesive curing reaction that occurs through the reaction of the isocyanate groups with the hydroxyls of the wood. Due to the high reactivity, the application time must be adjusted according to the manufacturer's recommendation (PIZZI, 1983).

The bonding of two pieces of wood depends on several factors, such as its anatomical structure, specific mass, and porosity. Iwakiri (2005) reports that the anatomical properties of wood are directly related to the mobility of the adhesive to the interior of the wood structure and the formation of bonding hooks between the bonding faces. The porosity has an inverse relationship with the specific mass, i.e., wood with specific high mass has less voids and, consequently, it hinders the penetration of the adhesive into the wood, reducing the anchorage and resulting in the low adhesion.

The amount of adhesive (weight) in forming the glue line between two pieces of wood is one of the specific parameters to promote good bonding. According to Fonte and Trianoski (2015), when the weight is lower or higher than the ideal, the strength of the bonded product is considerably altered. Very low weights imply lower resistance due to insufficient adhesion and anchoring. Higher grammages increase the opening time and pressing time and may also promote waste by spilling the excess of adhesive around the edges of the panels, resulting in economic losses (MARRA, 1992). Iwakiri et al. (2014) state that the range of weights most used by industries vary from 180 to $220 \mathrm{~g} / \mathrm{m}^{2}$.

In order to evaluate the potential of some eucalyptus species for the production of edge glued panels - EGP, this paper has the aim of analyzing the resistance of bonded joints of Eucalyptus camaldulensis and Eucalyptus urophylla woods made with PVA and EPI adhesives in two weights.

\section{MATERIAL AND METHODS}

Wood of Eucalyptus camaldulensis and Eucalyptus urophylla aged 16 years old, from plantations located in the Municipality of Corupá, State of Santa Catarina, Brazil, were used in this research.

Three trees were collected per species, which were sectioned into logs and transformed into planks. After drying, at the average humidity content of $12 \%$, the panels were unfolded and planed in slats with final dimensions of 22 (thickness) x 55 (width) x $310 \mathrm{~mm}$ (length). The apparent specific masses of wood of the two species were determined from these slats.

Polyvinyl acetate (PVA) adhesives with a viscosity of 3,000 cP, pH 4.5 and $45 \%$ solids content and isocyanate polymer emulsion (EPI) with a viscosity of $5,500 \mathrm{cP}, \mathrm{pH}$ of 8.0 and solids content of $42 \%$, were used for bonding the slats according to specifications provided by the manufacturer.

The adhesive was applied manually with a brush on one side of the slats in the weights of $150 \mathrm{~g} / \mathrm{m}^{2}$ (PVA) and $180 \mathrm{~g} / \mathrm{m}^{2}$ (EPI), controlled by weighing on a digital scale. The slats were glued in pairs with the application of specific pressure of $6.5 \mathrm{kgf} / \mathrm{cm}^{2}$. The pressing time was two hours for the PVA and one hour for the EPI. The experimental design consisted of two species, two patches and two weights, totaling 12 treatments, as presented in Table 1.

Table 1. Plano experimental.

Table 1. Experimental plan.

\begin{tabular}{lcccc}
\hline Treatment & Species & Sticker & Weight $\left(\mathbf{g} / \mathbf{m}^{\mathbf{2}}\right)$ & $\begin{array}{c}\text { Pressing time } \\
\text { (hour) }\end{array}$ \\
\hline T1 & & & 150 & 2 \\
T2 & & PVA & 180 & 2 \\
T3 & Eucalyptus & EPI & 150 & 1 \\
\cline { 3 - 4 } T4 & camaldulensis & 180 & 1 \\
\hline
\end{tabular}




\begin{tabular}{|c|c|c|c|c|}
\hline T5 & & \multirow[b]{2}{*}{ PVA } & 150 & 2 \\
\hline T6 & \multirow{3}{*}{ Eucalyptus urophylla } & & 180 & 2 \\
\hline $\mathrm{T} 7$ & & \multirow[b]{2}{*}{ EPI } & 150 & 1 \\
\hline $\mathrm{T} 8$ & & & 180 & 1 \\
\hline T9 & \multirow{4}{*}{$\begin{array}{l}\text { E. camaldulensis } \\
\text { and } \\
\text { E. urophylla }\end{array}$} & \multirow{3}{*}{ PVA } & 150 & 2 \\
\hline $\mathrm{T} 10$ & & & 180 & 2 \\
\hline $\mathrm{T} 11$ & & & 150 & 1 \\
\hline $\mathrm{T} 12$ & & EPI & 180 & 1 \\
\hline
\end{tabular}

After pressing, the glued joints were packed in the climatic chamber at a temperature of $20+3{ }^{\circ} \mathrm{C}$ and relative humidity of $65+5 \%$. Subsequently, samples were collected for shear tests of glue strip, which occurred in the EMIC brand machine, model DL 2000, in dry (after air conditioning) and wet conditions (after immersion in water at a temperature of $20 \pm 3{ }^{\circ} \mathrm{C}$ for $24 \mathrm{~h}$ ), according to the procedures described in standard EN 13354 (2008). The results were compared with the minimum requirement to the 5th inferior percentile, according to standard EN 13353 (2008). After the shear tests, the percentages of failure in the wood at the glue strip rupture surface were evaluated.

The statistical design was completely randomized with factorial arrangement of $2 \times 2 \times 2$ for species, adhesive, and weight. Initially, the variances of treatments were evaluated by their homogeneity through the Bartlett test and, then, were submitted to analysis of variance and Tukey test for comparison of averages, at the $95 \%$ probability level. Statistical tests were performed from the statistical package Statgraphics XVII.

\section{RESULTS}

\section{Density of Eucalyptus camaldulensis and Eucalyptus urophylla wood}

Table 2 shows the average, minimum and maximum values for apparent density of Eucalyptus camaldulensis and Eucalyputs urophylla wood.

Tabela 2 Densidade aparente da madeira das espécies estudadas.

Table 2. Apparent wood densities of the studied species.

\begin{tabular}{lcc}
\hline Density & E. camaldulensis & E. urophylla \\
\hline Average $\left(\mathrm{g} / \mathrm{cm}^{3}\right)$ & 0.824 & 0.717 \\
Minimum $\left(\mathrm{g} / \mathrm{cm}^{3}\right)$ & 0.646 & 0.528 \\
Maximum $\left(\mathrm{g} / \mathrm{cm}^{3}\right)$ & 0.983 & 0.931 \\
\hline Coef. Variation $(\%)$ & 10.84 & 17.51 \\
\hline
\end{tabular}

The average value of the apparent density of Eucalyptus camaldulensis wood was $0.824 \mathrm{~g} / \mathrm{cm}^{3}$ and $0.717 \mathrm{~g} / \mathrm{cm}^{3}$ for Eucalyptus urophylla.

\section{Shear strength of bonded joints - dry test}

Table 3 shows the results of shear strength of the bonded joints and percentage of failure in the wood for dry pre-treatment.

Tabela 3 Resultados médios dos ensaios das juntas coladas - teste seco.

Table 3. Average results of shear test of bonded wood joints - dry test.

\begin{tabular}{|c|c|c|c|c|c|}
\hline TR & Species & AD & GRA - g/m $\mathbf{m}^{2}$ & $f v-\mathrm{MPa}$ & FM - \% \\
\hline $\mathrm{T} 1$ & \multirow{4}{*}{$\begin{array}{c}\text { Eucalyptus } \\
\text { camaldulensis }\end{array}$} & \multirow[b]{2}{*}{ PVA } & 150 & $\begin{array}{l}14.66 \mathrm{ab} \\
(15.28)\end{array}$ & 31 \\
\hline $\mathrm{T} 2$ & & & 180 & $\begin{array}{l}14,84 \mathrm{a} \\
(15.18) .\end{array}$ & 69 \\
\hline $\mathrm{T} 3$ & & \multirow[b]{2}{*}{ EPI } & 150 & $\begin{array}{c}9.18 \mathrm{~d} \\
(33.12) .\end{array}$ & 31 \\
\hline $\mathrm{T} 4$ & & & 180 & $\begin{array}{l}11.58 \mathrm{bcd} \\
(20.54) .\end{array}$ & 20 \\
\hline T5 & \multirow{2}{*}{$\begin{array}{l}\text { Eucalyptus } \\
\text { urophylla }\end{array}$} & \multirow{2}{*}{ PVA } & 150 & $\begin{array}{l}10.93 \mathrm{~cd} \\
(26.68) .\end{array}$ & 42 \\
\hline T6 & & & 180 & $11.38 \mathrm{~cd}$ & 42 \\
\hline
\end{tabular}

FLORESTA, Curitiba, PR, v. 49, n. 2, p. 317-324, abr/jun 2019. 


\begin{tabular}{|c|c|c|c|c|c|}
\hline \multirow[b]{2}{*}{$\mathrm{T} 7$} & & & \multicolumn{3}{|c|}{ (23.32). } \\
\hline & & \multirow[b]{2}{*}{ EPI } & 150 & $\begin{array}{c}13.82 \mathrm{abc} \\
(23.14) .\end{array}$ & 50 \\
\hline \multicolumn{2}{|l|}{$\mathrm{T} 8$} & & 180 & $\begin{array}{c}12.57 \mathrm{abc} \\
(21.09) .\end{array}$ & 55 \\
\hline T9 & \multirow{4}{*}{$\begin{array}{c}\text { E. camaldulensis } \\
\text { and } \\
\text { E. urophylla }\end{array}$} & \multirow[b]{2}{*}{ PVA } & 150 & $\begin{array}{c}9.41 \mathrm{~d} \\
(26.53)\end{array}$ & 72 \\
\hline T10 & & & 180 & $\begin{array}{c}11.42 \mathrm{~cd} \\
(12.20)\end{array}$ & 65 \\
\hline $\mathrm{T} 11$ & & \multirow[b]{2}{*}{ EPI } & 150 & $\begin{array}{c}11.43 \mathrm{bcd} \\
(18.68)\end{array}$ & 53 \\
\hline $\mathrm{T} 12$ & & & 180 & $\begin{array}{c}12.85 \mathrm{abc} \\
(19.54)\end{array}$ & 40 \\
\hline
\end{tabular}

TR: treatment; AD: adhesive; GRA: weight; $f v$ : shear strength; FM: failure in the wood. Averages followed by the same letter in the column are statistically equal to each other at the $95 \%$ probability level; values in brackets refer to the coefficient of variation.

The average values of shear strength in the dry tests varied from $9.18 \mathrm{MPa}$ for bonded joints of $E$. camaldulensis with $150 \mathrm{~g} / \mathrm{m}^{2}$ of EPI adhesive (T3) and $14.84 \mathrm{MPa}$ for bonded joints of the same species with $180 \mathrm{~g} / \mathrm{m}^{2}$ of PVA adhesive (T2). Statistically significant differences were observed between treatments for different species, adhesives and weights.

As for the percentage of wood failures, there was a great amplitude in the results obtained. Values ranged from $20 \%$ for bonded joints of E. camaldulensis with $180 \mathrm{~g} / \mathrm{m}^{2}$ of EPI adhesive and $72 \%$ for bonded joints of E. camaldulensis and E. urophylla with $150 \mathrm{~g} / \mathrm{m}^{2}$ of PVA adhesive.

The results of the factorial analysis for dry pre-treatment, presented in Table 4, indicated statistically significant differences between the two species studied and a combination of these. $E$. camaldulensis presented the highest mean value among the treatments, followed by E. urophylla and the combination of the two species.

Tabela 4 Efeito da espécie na resistência ao cisalhamento - teste seco.

Table 4. Effect of the specie in the shear strength - dry test.

\begin{tabular}{lc}
\hline Species & Shear Strength (MPa) \\
\hline E. camaldulensis & $13.97 \mathrm{a}$ \\
E. urophylla & $11.66 \mathrm{a}$ \\
E. camaldulensis and E. urophylla & $10.40 \mathrm{a}$ \\
\hline Avaris
\end{tabular}

Averages followed by the same letter in the column are statistically equal to each other at the $95 \%$ probability level; values in brackets refer to the coefficient of variation.

Table 5 shows the results of the factorial analysis for the effects of the adhesive and weight for dry pre-treatment.

Tabela 5 Efeito do adesivo e gramatura na resistência ao cisalhamento - teste seco.

Table 5. Effect of adhesive and amount of glue in the shear strength - dry test.

\begin{tabular}{lc}
\hline Adesive & Shear Strength $(\mathbf{M P a})$ \\
\hline PVA & $12,02 \mathrm{a}$ \\
EPI & $11.84 \mathrm{a}$ \\
\hline Weight $\left(\mathbf{g} / \mathbf{m}^{\mathbf{2}}\right)$ & Shear Strength $(\mathbf{M P a})$ \\
\hline 180 & $12.44 \mathrm{a}$ \\
150 & $11.39 \mathrm{a}$ \\
\hline Averages followed by the same letter in the column are statistically equal to each other at the $95 \%$ probability level;
\end{tabular}

The results of the factorial analysis for the effects of the adhesive type indicated statistical similarity between the averages obtained for the PVA and EPI adhesives. Regarding the effects of weight, the factorial analysis indicated a statistically superior average for bonded joints with a weight of $180 \mathrm{~g} / \mathrm{m}^{2}$ in relation to the weight of $150 \mathrm{~g} / \mathrm{m}^{2}$.

\section{Shear strength of bonded joints - humid test}

Table 6 shows the results of shear strength of the glue strip and percentage of failure in the wood and $5^{\circ}$ inferior percentile for humid pre-treatment. 
Tabela 6 Resultados médios dos ensaios de cisalhamento das juntas coladas - teste úmido.

Table 6. Average results of shear test of bonded wood joints - humid test.

\begin{tabular}{|c|c|c|c|c|c|c|}
\hline TR & Species & AD & $\begin{array}{c}\text { GRA - } \\
\text { g/m² }\end{array}$ & $f v-\mathrm{MPa}$ & FM - \% & 5PI-MPa \\
\hline $\mathrm{T} 1$ & \multirow{4}{*}{$\begin{array}{c}\text { Eucalyptus } \\
\text { camaldulensis }\end{array}$} & \multirow[b]{2}{*}{ PVA } & 150 & $\begin{array}{c}6.18 \mathrm{bcd} \\
(0.22)\end{array}$ & 1 & 3.86 \\
\hline $\mathrm{T} 2$ & & & 180 & $\begin{array}{c}6.66 \mathrm{abcd} \\
(0.20)\end{array}$ & 0 & 4.89 \\
\hline T3 & & \multirow[b]{2}{*}{ EPI } & 150 & $\begin{array}{c}6.56 \mathrm{abcd} \\
(0.23)\end{array}$ & 5 & 4.61 \\
\hline $\mathrm{T} 4$ & & & 180 & $\begin{array}{c}6.59 \text { abcd } \\
(0.23)\end{array}$ & 1 & 4.50 \\
\hline $\mathrm{T} 5$ & \multirow{4}{*}{$\begin{array}{c}\text { Eucalyptus } \\
\text { urophylla }\end{array}$} & \multirow[b]{2}{*}{ PVA } & 150 & $\begin{array}{l}4.94 \mathrm{~d} \\
(0.20)\end{array}$ & 2 & 3.52 \\
\hline T6 & & & 180 & $\begin{array}{c}5.79 \mathrm{~cd} \\
(0.29)\end{array}$ & 4 & 3.17 \\
\hline $\mathrm{T} 7$ & & \multirow[b]{2}{*}{ EPI } & 150 & $\begin{array}{l}8.07 \mathrm{~d} \\
(0.22)\end{array}$ & 9 & 6.62 \\
\hline $\mathrm{T} 8$ & & & 180 & $\begin{array}{c}7.97 \mathrm{aB} \\
(0.21)\end{array}$ & 18 & 7.38 \\
\hline T9 & \multirow{4}{*}{$\begin{array}{c}\text { E. camaldulensis } \\
\text { and } \\
\text { E. urophylla }\end{array}$} & \multirow[b]{2}{*}{ PVA } & 150 & $\begin{array}{c}6.01 \mathrm{bcd} \\
(0.21)\end{array}$ & 7 & 4.69 \\
\hline $\mathrm{T} 10$ & & & 180 & $\begin{array}{c}6.36 \mathrm{abcd} \\
(0.19)\end{array}$ & 16 & 4.45 \\
\hline $\mathrm{T} 11$ & & \multirow[b]{2}{*}{ EPI } & 150 & $\begin{array}{c}7.72 \mathrm{aB} \\
(0.13)\end{array}$ & 13 & 6.01 \\
\hline $\mathrm{T} 12$ & & & 180 & $\begin{array}{c}7.56 \mathrm{abc} \\
(0.25)\end{array}$ & 5 & 4.06 \\
\hline
\end{tabular}

TR: treatment; AD: adhesive; GRA: weight; $f v$ : shear strength; FM: wood failure; 5PI: 5th inferior percentile. Averages followed by the same letter in the column are statistically equal to each other at the $95 \%$ probability level; values in brackets refer to the coefficient of variation.

The average values of shear strength in humid tests varied from $4.94 \mathrm{MPa}$ for bonded joints of $E$. urophylla with $150 \mathrm{~g} / \mathrm{m}^{2}$ of EPI adhesive (T5) and $8.07 \mathrm{MPa}$ for bonded joints of the same species with 150 $\mathrm{g} / \mathrm{m}^{2}$ of PVA adhesive (T7). Statistically significant differences were observed between treatments for different species, adhesives and weights.

As for the percentage of failure in the wood, the values obtained after humid pre-treatment were very low, having glue strip detachments for most treatments.

The 5th inferior percentile is an important parameter for assessing the quality of bonded joints after humid pre-treatment. The values obtained in this study ranged from 3.17 to $4.89 \mathrm{MPa}$ for PVA adhesive and from 4.06 to $7.38 \mathrm{MPa}$ for EPI adhesive.

The results of the factorial analysis for humid pre-treatment, presented in Table 7, indicated statistically significant differences between the two species studied and a combination of these. $E$. camaldulensis showed a statistically higher average in relation to E. urophylla and equal to the combination of these species.

Tabela 7 Efeito da espécie na resistência ao cisalhamento - teste úmido.

Table 7. Effect of the specie in the shear strength - humid test.

\begin{tabular}{lc}
\hline Species & Shear Strength (MPa) \\
\hline E. camaldulensis & $7.16 \mathrm{a}$ \\
E. urophylla & $6.47 \mathrm{ab}$ \\
E. camaldulensis and E. urophylla & $6.38 \mathrm{~b}$ \\
\hline Averages followed by the same letter in the column are statistically equal to each other at the 95\% probability level;
\end{tabular}

Table 8 shows the results of the factorial analysis for the effects of the adhesive and weight for humid pre-treatment.

Tabela 8 Efeito do adesivo e gramatura na resistência ao cisalhamento - teste úmido.

Table 8. Effect of adhesive and amount of glue in the shear strength - humid test.

FLORESTA, Curitiba, PR, v. 49, n. 2, p. 317-324, abr/jun 2019.

Iwakiri. S. et.al. 


\begin{tabular}{lc}
\hline Adesive & Shear Strength $(\mathbf{M P a})$ \\
\hline PVA & $7.22 \mathrm{a}$ \\
EPI & $6.13 \mathrm{~b}$ \\
\hline Weight $\left(\mathbf{g} / \mathbf{m}^{2}\right)$ & Shear Strength $(\mathbf{M P a})$ \\
\hline 180 & $6.72 \mathrm{a}$ \\
150 & $6.58 \mathrm{a}$ \\
\hline Averages followed by the same letter in the column are statistically equal to each other at the $95 \%$ probability level;
\end{tabular}

The results of the factorial analysis for the effects of the adhesive type indicated higher statistical average to the EPI adhesive in comparison to PVA. Regarding the effects of weight, the result of the factorial analysis did not indicate a significant difference between $150 \mathrm{~g} / \mathrm{m}^{2}$ and $180 \mathrm{~g} / \mathrm{m}^{2}$.

\section{DISCUSSION}

\section{Density of Eucalyptus camaldulensis and Eucalyptus urophylla wood}

The results obtained were higher than those mentioned by Lorenzi (2002) for commercially used eucalyptus species, such as: Eucalyptus grandis, Eucalyptus urograndis and Eucalyptus saligna, whose values were respectively $0.478,0.502$ and $0.462 \mathrm{~g} / \mathrm{cm}^{3}$.

According to the same authors, wood with a density below $0.5 \mathrm{~g} / \mathrm{cm}^{3}$, from $0.50 \mathrm{~g} / \mathrm{cm}^{3}$ to 0.72 $\mathrm{g} / \mathrm{cm}^{3}$ and above $0.72 \mathrm{~g} / \mathrm{cm}^{3}$ are classified, respectively, as low, medium and high density. Therefore, the wood of E. camaldulensis can be classified as high density, and of E. urophylla, as medium to high density.

It should be noted that the species most used in the production of EGP panels in Brazil are of low and medium density, as shown below: Tectona grandis ( 0.48 to $\left.0.64 \mathrm{~g} / \mathrm{cm}^{3}\right)$, Pinus elliottii and Pinus taeda (0.32 to $\left.0.34 \mathrm{~g} / \mathrm{cm}^{3}\right)$ and Eucalyptus grandis $\left(0.39\right.$ to $\left.0,51 \mathrm{~g} / \mathrm{cm}^{3}\right)$ (LOBÃO et al., 2011).

\section{Shear strength of bonded joints - dry test}

The results of shear strength of bonded joints obtained for the two species of Eucalyptus and a combination of these trees were compatible with those presented in the literature for eucalyptus, pinus and some tropical wood species glued with PVA adhesive. Iwakiri et al. (2013) found, for wood of Eucalyptus benthamii an average shear value of $9.04 \mathrm{MPa}$. Endo et al. (2017) obtained for wood Pinus taeda values between 5.12 and 5.55 MPa. Bila et al. (2016) found five species of tropical wood (Eschweilera coriacea, Manilkara amazonica, Protium puncticulatum, Inga paraensis and Byrsonima crispa) containing values between 2.24 and $8.45 \mathrm{MPa}$.

Regarding the joints bonded with EPI adhesive, Bila et al. (2016) found five species of tropical wood (Eschweilera coriacea, Manilkara amazonica, Protium puncticulatum, Inga paraensis and Byrsonima crispa) containing values between 6.85 and $14.38 \mathrm{MPa}$. Campelo et al. (2017) found, for Genipa americana wood, average value of $6.43 \mathrm{MPa}$.

The percentages of failure in the wood present great amplitude as a function of species and glue facets related to the growth direction of the tree. In this study, the two eucalypt species had an average density higher than 0.60 , being not necessary to evaluate the values obtained, according to the specifications described in standard EN-13354-2008. Plaster et al. (2008) founded for wood-bonded joints of Eucalyptus spp. with PVA adhesive the percentage of $26 \%$ to $91 \%$. Bila et al. (2016) founded for wood-bonded of six species of tropical woods with EPI adhesive percentages of failures in the range of $18 \%$ to $75 \%$.

The lower wood density of $E$. urophylla did not contribute to greater absorption of the adhesive and consequent increase in the resistance of the adhesive bonding of the bonded joints.

Several authors, among them Bila et al. (2016) found higher values of shear strength for bonded joints with EPI adhesive compared to PVA bonded joints.

The increase in the strength of bonded joints, for larger adhesive weights, was also observed by Iwakiri et al. (2015a) for woods of Japanese cryptomeria and Sequoia sempervirens.

\section{Shear strength of bonded joints - humid test}

The results obtained in the humid tests for the two species of Eucalyptus and a combination of these trees were satisfactory in relation to those presented in the literature for Pinus woods and some species of tropical woods, bonded with PVA and EPI adhesives. Endo et al. (2017) obtained for wood Pinus taeda bonded with PVA values between 3.36 and 5.36 MPa. Iwakiri et al. (2016) found for the woods of Protium 
puncticulatum and Dinizia excelsa, average shear values of 5.01 and 5.07 MPa for PVA and 3.14 and 4.11 $\mathrm{MPa}$ for EPI, respectively. Results of humid tests for eucalyptus-bonded joints were not found in the literature.

As for the percentage of failure in the wood, the values obtained after humid pre-treatment were very low, however, the standard EN-13354-2008 does not establish a minimum requirement for wood with a density higher than $0.60 \mathrm{~g} / \mathrm{cm}^{3}$. Detachments were observed in the glue strips for most treatments. As a reference, Iwakiri et al. (2015b) found for wood glued joints of Inga alba and Swartzia recurve, the percentage of wood failure of 2.0 to $3.0 \%$ for PVA adhesive and 3.0 to $32.33 \%$ for EPI.

The 5th inferior percentile is an important parameter for assessing the quality of bonded joints after humid pre-treatment. The values obtained in this study were higher for bonded joints with EPI, indicating that this adhesive is more resistant to humidity in comparison to PVA.

All treatments met the minimum requirement of $2.5 \mathrm{MPa}$, established by EN 13353-2003. As a reference, Iwakiri et al. (2005a) found, for wood-bonded joints of Cryptomeria japonica and Sequoia sempervirens, values of 5th inferior percentile after humid pre-treatment in the range of 1.44 to $180 \mathrm{MPa}$ for PVA adhesive and 3.78 to 5.35 MPa for EPI. Based on these references, the 5th inferior percentile values obtained in this study can be considered satisfactory.

E. camaldulensis showed a statistically higher average in relation to E. urophylla and equal to the combination of these species. However, even with higher density, these species had better shear results of the bonded joints in the humid trials compared to the lower density species, according to the references presented previously.

Comparisons between the two types of adhesives indicated the superiority of EPI to PVA. Iwakiri et al. (2016) and Campelo et al. (2017) also obtained higher values of shear strength for joints bonded with EPI adhesive in relation to PVA bonded joints.

Regarding the effects of weight, it was not observed a significant difference between $150 \mathrm{~g} / \mathrm{m}^{2}$ and $180 \mathrm{~g} / \mathrm{m}^{2}$. This result indicates the possibility of consuming a lesser amount of adhesive in the production of EGP panels with the wood of these species of Eucalyptus. Similar results were obtained by Campelo et al. (2017) and Iwakiri et al. (2016) for effects of weight of bonded joints strength.

\section{CONCLUSIONS}

- The wood of Eucalyptus camaldulensis and Eucalyptus urophylla have high apparent density, however, this characteristic did not contribute to reduction of the shear bond strength of the bonded joints, as a consequence of the lower porosity and greater difficulty in the penetration of the adhesive in the subsurface of the wood damaging the anchorage.

- The results of the shear tests of the bonded joints in the dry tests were satisfactory in comparison to the data presented in the literature for pine, eucalyptus and some tropical species.

- In the shear tests, after humid pre-treatment, all treatments met the minimum requirement of $2.5 \mathrm{MPa}$, referring to the 5th inferior percentile, as established by EN 13353 (2008).

- For both dry and humid testing, Eucalyptus camaldulensis showed better shear results compared to Eucalyptus urophylla and a combination of these species. EPI adhesive presented better bonding results than PVA in the humid assays. The increase in weight resulted in higher shear strength only in the dry tests.

- Based on the general evaluation of the results, it can be stated that the wood of Eucalyptus camaldulensis and Eucalyptus urophylla, present great potential for the production of side bonding panels - EGP.

\section{ACKNOWLEDGMENTS}

The authors would like to thank the Uniedu Post-Graduation Program, as well as the Coordination of Personnel Improvement of Higher Education -- Capes for the financial contribution.

\section{REFERENCES}

BILA, N. F.; IWAKIRI, S.; TRIANOSKI, R.; PRATA, J. G Avaliação da qualidade de juntas coladas de seis espécies de madeiras tropicais da Amazônia. Floresta, Curitiba, v. 46, n. 4, p. 455 - 464, 2016.

BOLAND, D. J.; BROOKER, M. I. H.; CHIPPENDALE, G. M.; HALL, N.; HYLAND, B. P. M.; JOHNSTON, R. D. Forest trees of Australia. Melbourne: CSIRO Publishing. 2006, 355 p.

FLORESTA, Curitiba, PR, v. 49, n. 2, p. 317-324, abr/jun 2019.

Iwakiri. S. et.al. 
CAMPELO, S.; IWAKIRI, S.; TRIANOSKI, R.; AGUIAR, O. R. Utilização da madeira de Genipa americana para produção de painéis de colagem lateral - EGP. Floresta, Curitiba, v. 47, n. 1, p. 129 - 135 , 2017.

ENDO, C.; TRIANOSKI, R.; IWAKIRI, S. Produção de EGP com diferentes adesivos PVAc e sistemas de prensagem. Floresta e Ambiente, v. 24, p. 1 - 8, 2017.

EUROPEAN COMMITTEE FOR STANDARDIZATION - CEN. EN 13353. Solid wood panels (SWP) Requirements. Bruxelas, 2008.

EUROPEAN COMMITTEE FOR STANDARDIZATION - CEN. EN 13354. Solid wood panels (SWP) bonding quality. Bruxelas, 2008

FONTE, A. P. N.; TRIANOSKI, R. Efeito da gramatura sobre a qualidade de colagem lateral da madeira de Tectona grandis. Revista de Ciências Agroveterinárias, v. 14, n. 3, p. 224-233, 2015.

IWAKIRI, S. Painéis de Madeira Reconstituída. Curitiba: FUPEF. 2005, 254 p.

IWAKIRI, S.; TRIANOSKI, R.; CUNHA, A. B.; PRATA, J. G.; HARA, M.; BILA, N. F.; LUIS, R. C. G.; ARAUJO, R. D.; VILLAS BÔAS, B. T. Avaliação da resistência de juntas coladas da madeira de Eucalyptus benthamii com diferentes adesivos e faces de colagem. Scientia Forestalis, v. 41, n. 99 , p. 411 - 416, 2013.

IWAKIRI, S.; MATOS, J. L. M.; TRIANOSKI, R.; PARCEHN, C. F. A.; CASTRO, V. G.; IWAKIRI, V. T. Características de vigas laminadas coladas confeccionadas com madeira de teca (Tectona grandis). Floresta e Ambiente, v. 21, n. 2, p. 269 - 275, 2014.

IWAKIRI, S.; TRIANOSKI, R.; FRANÇA, R. F.; GONÇALVES, T. A. P.; LOIOLA, P. L.; CAMPELO, S. R.; FARIAS, R. F. Avaliação da resistência de juntas coladas da madeira de Cryptomeria japônica e Sequoia sempervirens com diferentes adesivos. Scientia Forestalis, v. 43, n. 105, p. 19 - 26, 2015 a.

IWAKIRI S.; TRIANOSKI, R.; NASCIMENTO, C. C.; GUMANE, C.; LENGOWSKI, E. C.; SCHARDOSIN, F. A.; AZAMBUJA, R. Resistência das juntas coladas de madeiras de Inga alba (SW) Wild e Swartzia recurva Poep. Cerne, v. 21, 3, p. 457 - 463, 2015 b.

IWAKIRI, S.; TRIANOSKI, R.; FONTE, A. P. N.; FRANÇA, M. C.; LAU, P. C.; MOLLEKEN, R. Potencial de uso de madeias de Dinizia excelsa Ducke e Protium puncticulatum J. F. Mach para produção de painéis EGP. Scientia Forestalis, v. 44, n. 111, p. 709 - 717, 2016.

JUNIOR, L. S.; GARCIA, GARCIA, J. N. Determinação das propriedades físicas e mecânicas da madeira de Eucalyptus urophylla. Scientia forestalis, v. 65, p. $120-129,2004$.

LOBÃO, M. S.; CASTRO, V. R.; RANGEL, A.; SARTO, C.; TOMAZELlO FILHO, M.; SILVA JUNIOR, F. G.; CAMARGO NETO, L.; BERMUDEZ, M. A. R. C. Agrupamento de espécies florestais por análises univariadas e multivariadas das características anatômica, física e química das suas madeiras. Scientia Forestalis, v. 18, n. 1, p. 16 - 29, 2011.

LORENZI, H. Árvores brasileiras: manual de identificação e cultivo de plantas arbóreas nativas do Brasil. Nova Odessa: Instituto Plantarum. 2002, 255 p.

MARRA, A. A. Technology of wood bonding: principles in practice. New York: Van Nostrand Reinhold. 1992, 453 p.

PIZZI, A. Wood adhesives: Chemistry and Technology. New York: Marcel Dekker. 1983, 364 p.

PLASTER, O. B.; OLIVEIRA, J. T. S.; ABRAHÃO, C. P.; BRAZ, R. L. Comportamento de juntas coladas da madeira serrada de Eucalyptus sp. Cerne, v. 14, n. 3, p. 251 - 258, 2008.

TIENNE, D. L. C.; NASCIMENTO, A. M.; GARCIA, R. A.; SILVA, D. B. Floresta e Ambiente, v. 18, n. 1, p. 16-29, 2011. 